\title{
PUBLISITAS
}

Journal of Social Sciences and Politics

Vol. 7 No. 2 April 2021

p-ISSN : 2252-4150

e-ISSN : 2716-3474

Tersedia online di http://ejurnal.stisipolcandradimuka.ac.id/index.php/JurnalPublisitas/

\section{Kajian Implementasi Permendes Nomor 19 Tahun 2017 Dalam Penetapan Prioritas Penggunaan Dana Desa di Kabupaten Barito Kuala}

\author{
Farah Qubayla ${ }^{1}$, Jamaluddin ${ }^{2}$, \\ ${ }^{1}$ Ilmu Pemerintahan, Fakultas Ilmu Sosial dan Ilmu Politik, Univeristas Lambung Mangkurat - Jalan H. \\ Hasan Basry, Banjarmasin, Kalimantan Selatan \\ ${ }^{2}$ Magister Ilmu Pemerintahan, Fakultas Ilmu Sosial dan Ilmu Politik, Univeristas Lambung Mangkurat - \\ Jalan H. Hasan Basry, Banjarmasin, Kalimantan Selatan \\ E-mail: farah.qubayla@ulm.ac.id; jamaluddin.fisip@ulm.ac.id
}

\begin{abstract}
ABSTRAK
Permendes Nomor 19 Tahun 2017 adalah peraturan yang dikeluarkan Kementerian Desa, Pembangunan Daerah Tertinggal, dan Transmigrasi untuk mengatur prioritas penggunaan dana desa tahun di Indonesia padah tahun 2018. Penetapan prioritas tersebut ditujukan agar para pemerintah daerah maupun kabupaten/kota memiliki pedoman dalam penggunaan dana desa yang setiap tahunnya diberikan oleh pemerintah, sekaligus menjadi salah satu acuan dalam penyusunan teknis maupun evaluasi pelaksanaan penggunaan dana desa. Penelitian ini menggunakan metode kualitatif dan dilakukan untuk mengkaji permasalahan implementasi Permendes No. 19 Tahun 2017 dan rekomendasi berupa langkah konkrit yang perlu dilakukan pemerintah di Kabupaten Barito Kuala. Temuan dan rekomendasi dalam penelitian ini dihasilkan dari kajian normatif kebijakan terkait dengan Permendes No. 19 Tahun 2017 maupun kajian empiris pada penggunaan dana desa di delapan desa terpilih di berbagai kecamatan di Kabupaten Barito Kuala. Melalui penelitian ini diketahui bahwa terdapat faktor-faktor yang sangat mempengaruhi implementasi kebijakan ini yaitu komunikasi, sumber daya, disposisi dan struktur birokrasi dalam pengelolaan dana desa. Dana desa yang diterima di seluruh desa yang ada Kabupaten Barito Kuala pada umumnya diprioritaskan untuk pembangunan infrastrukstur yang menyerap sekitar $70 \%$ dari keseluruhan dana. Melalui penelitian ini harapannya akan tersedia sebuah rancangan model penetapan prioritas penggunaan dana desa yang dimungkinkan dapat menurunkan angka kemiskinan pedesaan di Kabupaten Barito Kuala.
\end{abstract}

Kata kunci : implementasi, kebijakan, dana desa, kemiskinan.

\section{ABSTRACT}

Permendes Number 19 of 2017 is a regulation issued by the Ministry of Villages, Development of Disadvantaged Areas, and Transmigration to regulate priorities for the use of village funds in Indonesia in 2018. This prioritization is intended so that local and district / city governments have guidelines in using village funds annually provided by the government, as well as being one of the references in technical preparation and evaluation of the implementation of the use of village funds. This study used qualitative methods and was conducted to study the implementation problems of Permendes No. 19 of 2017 and recommendations in the form of concrete steps that need to be taken by the government in Barito Kuala Regency. The findings and recommendations in this study resulted from a 
normative review of policies related to the Permendes No. 19 of 2017 as well as empirical studies on the use of village funds in eight selected villages in various sub-districts in Barito Kuala Regency. Through this research it is known that there are factors that greatly influence the implementation of this policy, namely communication, resources, disposition and bureaucratic structure in the management of village funds. Village funds received in all villages in Barito Kuala Regency are generally prioritized for infrastructure development, which absorbs about $70 \%$ of the total funds. Through this research, it is hoped that there will be a design model for determining the priority of the use of village funds which is possible to reduce the rural poverty rate in Barito Kuala Regency.

Keywords: implementation, policy, village fund, poverty.

\section{PENDAHULUAN}

Pemerintah Indonesia telah banyak menyusun kebijakan-kebijakan yang ditujukan untuk penanggulanagn kemiskinan dan juga tidak terlepas dari peranan dari kementerian sektoral seperti Kemendesa sendiri. Kemudian yang menjadi pertanyaan adalah apakah pemerintah telah cukup dalam melaksanakan penanggulangan kemiskinan di Indonesia terutama di daerah-daerah tertinggal. Dan selama ini pemerintah memang telah banyak mengeluarkan kebijakan terkait permasalahan kemiskinan, salah satunya dengan adanya Dana Desa. Setiap tahun pemerintah menganggarkan dana desa yang bersumber dari APBN untuk diberikan kepada desa-desa di Indonesia sejak tahun 2015 hingga sekarang. Tetapi fakta-fakta masih menimbulkan pertanyaan mengapa kemiskinan begitu sulit diturunkan. Untuk menjawab pertanyaan ini dalam konteks kebijakan, adalah bahwa selama ini upaya pengentasan kemiskinan fokus memberikan penekanan pada pemenuhan sandang, pangan dan papan bagi masyarakat miskin. Tetapi tidak memperhatikan faktor lain yang bersifat non agregat yang dapat menumbuhkan masyarakat dengan kemampuan serta kapasitas untuk mandiri. Diantaranya dengan mendorong masyarakat untuk memiliki nilai-nilai, seperti: harga diri (self esteem), kebanggaan (dignity), kemandirian (independence), pengakuan (recognition) dan kebebasan (freedom) [1].

Sehingga upaya pengentasan kemiskinan yang dilakukan oleh pemerintah selama ini tidak mampu membuat masyarakat miskin untuk dapat berdiri sendiri, sebaliknya kebijakan yang ada justru membuat masyarakat menjadi sangat ketergantungan dengan bantuan dari pemerintah. Padahal salah satu upaya yang dapat mendorong kemandirian masyarakat miskin adalah dengan melakukan usaha atau kegiatan yang bersifat produktif melalui program pemberdayaan masyarakat. Perlu diakui bahwa program pemberdayaan masyarakat juga merupakan salah satu prioritas dalam penggunaan dana desa, akan tetapi apakah program tersebut kemudian menjadi prioritas utama dan telah dijalankan dengan baik? Karena selama ini penggunaan dana desa jauh lebih diprioritaskan pada pembangunan infrastruktur dibandingkan dengan pemberdayaan masyarakat untuk 
melakukan usaha-usaha produktif yang dapat menumbuhkan kemandirian mereka.

Penelitian ini bertujuan untuk mengkaji bagaimana implementasi dari salah satu diantara beragam upaya pemerintah melalui berbagai kebijakannya dalam pengentasan kemiskinan adalah Peraturan Menteri Desa (Permendes) nomor 19 tahun 2017 tentang penetapan prioritas penggunaan Dana Desa tahun 2018 telah berjalan dan karena itu perlu dilakukan penelitian. Dalam peraturan ini pada pasal 2, telah menentukan bahwa penetapan prioritas penggunaan dana desa bertujuan a) memberikan acuan bagi penyelenggaraan kewenangan hak asal usul dan kewenangan lokal berskala Desa yang dibiayai oleh Dana Desa dalam melaksanakan program dan kegiatan; b) memberikan acuan bagi Pemerintah Daerah Kabupaten/Kota dalam menyusun pedoman teknis penggunaan Dana Desa; dan c) memberikan acuan bagi Pemerintah Daerah Pusat dalam pemantauan dan evaluasi pelaksanaan penggunaan Dana Desa [2]. Kemudian pada pasal 5 ditentukan bahwa Dana Desa digunakan untuk membiayai pembangunan Desa yang ditujukan untuk meningkatkan kesejahteraan masyarakat Desa, peningkatan kualitas hidup manusia serta penanggulangan kemiskinan dengan prioritas penggunaan Dana Desa diarahkan untuk pelaksanaan program dan kegiatan Pembangunan Desa [2].

Ketentuan bahwa penanggulangan kemiskinan dapat dilakukan melalui penetapan prioritas penggunaan dana desa yang ditetapkan oleh Kemendesa berdasarkan Permendes No. 19 tahun 2017, maka penelitian ini penting dilakukan, khususnya sebagai upaya penurunan angka kemiskinan di beberapa desa di Kabupaten Barito Kuala, Provinsi Kalimantan Selatan.

\section{TINJAUAN PUSTAKA Implementasi Kebijakan}

Implementasi kebijakan adalah salah satu proses yang paling krusial dan kompleks dalam siklus hidup kebijakan. Implementasinya merupakan proses yang rumit karena menyangkut masalah politik, keuangan dan administrasi, dan ini membutuhkan motivasi, lobi yang tepat, dan dukungan teknis, profesional dan administratif. Keberhasilan implementasi kebijakan akan ditentukan oleh banyak variabel atau faktor, dan masing-masing variabel tersebut saling berhubungan satu sama lain.

Jika dilihat sebagai konsep umum, implementasi kebijakan dapat didefinisikan sebagai tahap ketiga dari siklus kebijakan yang berarti tahap proses kebijakan segera setelah berlakunya undang-undang, atau tindakan yang akan diambil untuk menempatkan hukum berlaku atau bahwa masalah akan diselesaikan. Implementasi juga dapat didefinisikan dalam hal keluaran (output), atau sejauh mana tujuan program didukung atau dipergunakan, seperti tingkat pengeluaran yang berkomitmen untuk program.

Implementasi kebijakan dapat dipahami sebagai cara atau upaya yang dilakukan pemerintah agar sebuah keputusan atau kebijakan dapat mencapai tujuannya [3]. Kemudian Lester dan Stewart juga menjelaskan bahwa implementasi sebuah kebijakan secara luas dapat diartikan sebagai alat jika 
dipandang dalam pengertian luas merupakan alat administrasi hukum mengenai bagaimana aktor, organisasi, prosedur, dan teknik bekerja sama untuk menerapkan kebijakan yang diadopsi dalam upaya untuk mencapai dampak atau tujuan yang diinginkan [4].

\section{Indikator Keberhasilan Implementasi Kebijakan}

Kompleksitas implementasi tidak hanya disebabkan oleh banyaknya aktor atau unit organisasi yang terlibat, akan tetapi juga dikarenakan proses implementasi dipengaruhi oleh berbagai variabel yang kompleks pula, baik variabel yang individual maupun variabel organisasional. Dan masing-masing variabel pengaruh tersebut juga saling berinteraksi satu sama lain. Variabelvariabel tersebut dapat ditemukan dalam berbagai model implementasi kebijakan oleh para ahli yang dapat digunakan untuk menganalisis variabel-variabel yang mempengaruhi keberhasilan sebuah kebijakan.

Implementasi kebijakan publik dapat dilihat dari beberapa perspektif atau pendekatan. Salah satunya adalah pendekatan yang diperkenalkan oleh George C. Edwards III yaitu implementation problems approach [5]. Jika suatu kebijakan tidak tepat atau tidak dapat mengurangi masalah yang menjadi sasaran dari sebuah kebijakan, maka kebijakan tersebut mungkin akan mengalami kegagalan sekalipun kebijakan telah dengan sangat baik diimplementasikan. Sementara itu, suatu kebijakan yang telah direncanakan dengan sangat baik, mungkin juga akan mengalami kegagalan, apabila kebijakan tersebut kurang diimplementasikan dengan baik oleh pelaksana kebijakan.

George C. Edwards III dalam mengkaji implementasi kebijakan berangkat dari dua hal pokok yaitu mengenai faktor pendukung dan penghambat dalam menentukan keberhasilan implementasi kebijakan [6]. Berdasarkan dua pertanyaan tesebut kemudian Edwards III merumpuskan beberapa variabel yang krusial variabel krusial dalam menentukan keberhasilan sebuah implementasi kebijakan yang pada akhirnya akan mempengaruhi keberhasilan suatu kebijakan atau tidak, yaitu komunikasi, sumber daya, disposisi dan struktur birokrasi. Empat hal tersebut yang kemudian dapat dijadikan sebagai alat analisis dalam mengkaji implementasi sebuah kebijakan.

\section{Komunikasi}

Implementasi kebijakan akan dapat dikatakan berhasil jika para pelaksana kebijakan atau bisa disebut sebagai implementor kebijakan mengetahi dan memahami apa yang harus dilakukan guna mencapa tujuan dari kebijakan tersebut. Selain itu, tujuan dan sasaran dari kebijakan kemudian haris disampaikan atau ditransmisikan kepada kelompok sasarannya, misalnya masyarakat. Melalui transmisi tersebutharapannya akan mengurangi distorsi dalam proses implementasi. Sebaliknya jika tujuan dan sasaran dari sebuah kebijakan tidak memiliki kejelasan atau tidak ditransmisikan kepada kelompok sasaran sehingga mereka tidak mengetahuinya sama sekali, maka akan sangat mungkin terjadi resistensi dari kelompok sasaran sebagai konsekuensi dari ketiadaan informasi [6]. Sehingga dapat dipahami semakin baik komunikasi yang terjadi diantara pihakpihak terlibat dalam proses implementasi sebuah kebijakan, maka akan semakin kecil resiko terjadinya kesalahpahaman atau miskomunikasi di dalamnya dan begitu pula sebaliknya. 
Adapun beberapa macam dimensi dalam komunikasi yang dikemukakan oleh Edwards III, yaitu: "orders to implement policies must be clear, accurate and consistent" [5]. Berdasarkan pernyataan tersebut diketahui bahwa dimensi komunikasi yang dimaksud adalah transmisi (transmission), kejelasan (clarity) dan konsistensi (consistency) [5]. Menurut Edwards III, persyaratan utama dalam implementasi seperti yang telah disebutkan sebelumnya bahawa para pelaksana kebijakan harus mengetahui apa yang harus mereka lakukan. Apapun keputusan maupun perintah harus ditransmisikan atau diteruskan kepada pihak-pihak yang tepat sebelum keputusan atau peraturan tersebut dapat diikuti. Sehingga menjadi sangat penting sekali untuk memastikan bahwa komunikasi-komunikasi yang akan disampaikan harus akurat dan dapat dipamahi dengan cermat oleh para pelaksana kebijakan. Dan sayangnya, tidak dapat dipungkiri bahwa banyak sekali yang dapat menjadi hambatan dalam proses transmisi komunikasi dalam implementasi kebijakan. Hambatan tersebut pada akhirnya hanya akan menghambat dan menghalangi proses implementasi sebuah kebijakan dalam mencapai tujuannya.

\section{Sumber Daya}

Secara logis sudah dapat dimengerti ketika keputusan-keputusan maupun perintah-perintah yang akan disampaikan kepada implementor atau pelaksana kebijakan harus disampaikan dan dikomunikasikan secara cermat, jelas dan konsisten. Akan tetapi apabila terjadi para pelaksananya kebijakan memiliki kekurangan sumber daya yang diperlukan untuk mendukung pelaksanaan kebijakan, maka implementasinya pun akan berjalan sesuai dengan harapan. Sumber daya yang dimaksud dalam hal ini tidak hanya berupa sumber daya manusia secara kuantitas saja tetapi juga termasuk didalamnya kompetensi pelaksana kebijakan dan sumber daya finansial. Tanpa sumber daya, dapat dipastikan sebuah kebijakan hanya akan menjadi sebuah dokumen belaka yang tidak akan berjalan untuk mencapai tujuannya [6].

Edwards III menjelaskan bahwa sumber-sumber yang dapat menentukan keberhasilan pelaksanaan salah satunya adalah sumber daya yang tersedia, karena sumber daya merupakan sumber penggerak dan pelaksana. Sumber daya manusia merupakan sumber daya yang paling penting dalam menentukan apakah sebuah kebijakan akan berhasil pelaksanaannya atau tidak. Sehingga secara keseluruhan sangat pentinh untuk dipahami bahwa keberhasilan sebuah implementasi kebijakan akan sangat dipengaruhi oleh bagaimana pemanfaatan sumber daya manusia, biaya dan waktu. Kemudian Edwards III lebih lanjut memaparkan bahwa ada empat komponen yang dapat dikaji dalam variabel sumber daya ini, antara lain: 1) staf yang cukup (baik dalam jumlah dan mutu); 2) informasi yang dibutuhkan dalam upaya pengambilan keputusan; 3) kewenangan yang cukup guna melaksanakan tugas atau tanggung jawab; dan 4) fasilitas yang dibutuhkan dalam pelaksanaan [6].

\section{Disposisi}

Disposisi atau sikap pelaksana dapat dipahami sebagai komitmen pelaksana terhadap program kebijakan [6]. Disposisi menurut Edwards III, merupakan faktor penting dalam pendekatan mengenai implementasi kebijakan. Apabila menginginkan kegiatan implementasi efektif, maka para pelaksana atau implementor tidak hanya harus mengetahui apa yang akan 
dilakukan tetapi juga harus memiliki kemampuan untuk melaksanakannya [6]. Kemampuan untuk melaksanakan tersebut menjadi kualitas atau ciri-ciri dari para aktor pelaksana guna mendukung keberhasilan implementasi kebijakan. Edwards III menekankan bahwa keberhasilan kebijakan bisa dilihat dari disposisi (karakteristik agen pelaksana) [5]. Variabel disposisi ini sangat penting karena kinerja implementasi sangat dipengaruhi oleh sifat ataupun ciri-ciri dari pelaksana tersebut. Apabila implementor memiliki sifat atau karakteristik yang baik, maka dia akan dapat menjalankan kebijakan dengan baik seperti apa yang diinginkan oleh pembuat kebijakan [5], [6].

\section{Struktur Birokrasi}

Variabel terakhir yang juga sama pentingnya dengan ketiga variable sebelumnya adalah struktur birokrasi dimana mereka merupakan pihak yang bertugas dan memiliki pengaruh yang signifikan dalam proses implementasi kebijakan [6]. Struktur birokrasi atau organisasi suatu badan dapat dipahami sebagai variabel yang memiliki peranan penting dalam menentukan keberhasilan dari implementasi kebujakan. Sehingga dibutuhkan struktur birokrasi yang tertata dengan baik untuk mendukung tercapainya tujuan kebijakan yang telah disepakati dan ditetapkan. Salah satu aspek dama struktur biroktasi yang paling penting adalah ketersediaan prosedur operasional yang jelas atau lebih dikenal sebagai SOP/POS yang dapat dijadikan sebagai pedoman dalam pelaksanaan kegiatan guna mendukung implementasi kebijakan oleh para pelaksana kebijakan atau implementor. Sedangkan struktur birokrasi yang terlalu panjang dan berbelit justru akan menghambat implemetasi kebijakan karena akan cenderung melemahkan pengawasan dan menimbulkan prosedur birokrasi yang rumit dan kompleks. Sehingga aktivitas organisasi akan menjadi sangat kaku, tidak dinamis dan tidak fleksibel [6].

Empat variabel yang telah dipaparkan diatas merupakan variabel yang bekerja secara simultan dan berhubungan satu sama lain untuk mendukung maupun sebaliknya (menghambat, jika variabel tersebut tidak terlaksana dengan baik) implementasi kebijakan. Dengan demikian dapat dipahami bahwa pendekatan yang ideal dalam mengkaji penelitian ini adalah dengan merefleksikan dan membahas keempat variabel tersebut sekaligus. Karena implementasi kebijakan merupakan sebuah proses yang dinamis dimana terjadi banyak interaksi antara variabel yang mempengaruhinya. Dengan menggunakan keempat variabel tersebut maka akan dapat diketaui bagaimana implementasi kebijakan Permendes No. 19 Tahun 2017 dalam pengelolaan dana desa di Kabupaten Barito Kuala.

\section{METODE PENELITIAN}

Penelitian ini menggunakan pendekatan penelitian kualitatif sehingga diharapkan mampu menggambarkan secara utuh atas subyek penelitian. Fokus penelitian adalah menjawab permasalahan yang telah dirumuskan dan memenuhi tujuan penelitinnya. Jacob Vredenberg [7] menguraikan dalam bukunya bahwa ada beberapa hal yang yang mendasari penggunaan pendekatan kualitatif dalam suatu penelitian, yaitu: (1) penelitian kualitatif menyajikan bentuk yang menyeluruh (holistic) dalam menganalisis suatu fenomena; penelitian jenis ini lebih peka menangkap informasi kualitatif deskriptif, dengan cara relatif tetap berusaha 
mempertahankan keutuhan (wholeness) dari obyek, yang berarti bahwa data yang dikumpulkan dipelajari sebagai keseluruhan yang terintegrasi.

Penelitian mengenai kajian implementasi ini dilakukan di Barito Kuala yang merupakan salah satu kabupaten di Provinsi Kalimantan Selatan terhadap perangkat daerah yang secara langsung terkait dengan implementasi kebijakan Permendes No. 19 Tahun 2017 tentang prioritas penggunaan dana desa tahun dalam upaya penurunan angka kemiskinan pedesaan.

$$
\text { Adapun langkah-langah }
$$
pengumpulan data yang dilakukan oleh peneliti, yaitu: pertama, proses memasuki lokasi penelitian (getting in) yaitu umpulan data dari informan yang ditentukan dengan cara purposive sampling dilakukan dengan kunjungan ke lokasi penelitian. Dengan mendatangi kantor Sekretariat Daerah, BAPPEDA, BPMPD, Kecamatan dan Desa terpilih. Kedua, proses pengumpulan data di lokasi penelitian saat terjun secara langsung ke lapangan dengan melakukan penyesuaian dengan para informan serta menghindari suasana yang kaku dan formal (getting along). Ketiga, proses pengumpulan data (logging the data) berdasarkan hasil wawancara mendalam (indepth interview) serta studi litertaur atau dokumentasi.

\section{HASIL PENELITIAN}

Barito Kuala merupakan salah satu kabupaten di provinsi Kalimantan Selatan yang memiliki potensi ekonomi sangat besar pada sektor pertanian khususnya pertanian tanaman pangan. Bahkan sektor ini menjadi sektor unggulan kabupaten karena nilainya yang terus meningkat setiap tahunnya. Dengan merujuk data dari PDRB (Produk Domestik Regional Bruto) Kabupaten Barito Kuala yang dibuat oleh BPS diketahui bahwa sektor pertanian, kehutanan dan perikanan memberikan kontribusi paling besar terhadap pertumbuhan ekonomi di wilayah ini [8]. Sektor industri pengolahan dan sektor konstruksi merupakan sektor lainnya yang berpotensi untuk berkembang meski nilainya masih berada jauh di bawah sektor pertanian.

Secara administratif, kabupaten Barito Kuala memiliki 17 kecamatan dengan 195 desa dan 6 buah kelurahan. Penelitian ini memilih delapan kecamatan secara purposive sampling yang didasarkan pada pertimbangan penyebaran geografis, potensi ekonomi kecamatan dan jumlah penduduk miskin di kecamatan tersebut. Hal ini menjadi penting untuk diperhatikan mengingat tujuan penelitian adalah untuk mengetahui pola atau model pemberdayaan masyarakat desa yang mampu memberikan dampak positif dalam mengurangi angka kemiskinan di kabupaten Barito Kuala secara umum.

Melalui diskusi dengan beberapa narasumber terkait, yaitu kepala BPMPD Barito Kuala, dan kepala Bidang Sosial dan Budaya Badan Perencanaan Daerah (BAPPEDA) Barito Kuala maka penelitian ini memilih delapan kecamatan untuk menjadi objek penelitian, yaitu kecamatan Tamban, kecamatan Alalak, kecamatan Jejangkit, kecamatan Kuripan, 
kecamatan Tabukan, kecamatan Anjir Muara, kecamatan Mandastana, dan kecamatan Rantau Badauh.

Dari keseluruhan delapan desa yang menjadi objek penelitian ini, hanya ada satu perangkat desa di salah satu desa saja yang mengetahui mengenai Permendes No. 19 tahun 2017. Beliau adalah sekretaris desa di Pantai Hambawang, Kecamatan Mandastana. Sedangkan semua perangkat desa lainnya dan masyarakat hanya mengetahui adanya dana desa yang ditujukan untuk setiap desa. Tanpa mengetahui bahwa dana desa yang diterima oleh setiap desa juga telah diatur dan ditetapkan prioritas pembangunannya melalui Permendes No. 19 Tahun 2017 yang menjadi salah satu acuan dari dibuatnya Peraturan Bupati Barito Kuala Nomor 120 Tahun 2017. Sebagai contoh di desa Sungai Gampa, Kecamatan Rantau Bedauh, baik Sekretaris Desa dan perangkat desa lainnya tidak mengenal apa itu Permendes No. 19 Tahun 2017. Mereka hanya mengetahui dana desa yang perlu dialokasikan dan diserahkan kepada kaur perencanaan dan keuangan. Begitu pula yang terjadi di Desa Balandean, Kecamatan Alalak dan lima desa lainnya. Disini terlihat bawa dalam upaya komunikasi kebijakan Permendes No. 19 Tahun 2017, proses transmisi dan kejelasan komunikasinya belum optimal. Karena tidak semua pelaksana kebijakan (perangkat desa) mengetahui nama dari kebijakan tersebut, begitupula mengenai isinya. Para pelaksana kebijakan hanya memiliki informasi mengenai sasaran dan tujuan dari pengalokasian dan pengelolaan dana desa berdasarkan beberapa Peraturan Bupati Barito Kuala khususnya Nomor 120 Tahun 2017 [9].

Meskipun tidak mengetahui nama kebijakan yang ditetapkan, seluruh perangkat desa memiliki pengetahuan baik mengenai prioritas dan tujuan dari penggunaan dana desa yang diterima. Dan pengelolaan dana tersebut sudah diupayakan terlaksana sebagaimana mestinya terutama dalam upaya pembangunan desa. Komunikasi yang terjalin antar perangkat desa dan juga masyakarat dalam pengelolaan dana desa pun berjalan dengan cukup baik. Pelaksanaan atau implementasi sebuah kebijakan dapat dikatakan efektif dijalankan jika para pembuat keputusan benar-benar mengetahui dan memahami apa yang harus dan akan dikerjakan. Dan hal tersebut akan dapat dicapai apabila komunikasi yang terjadi di lingkup birokrasi kebijakan berjalan dengan baik. Agar semua keputusan maupun peraturan harus benar-benar dapat disampaikan secara tepat sasaran.

Semua perangkat pemerintah desa ikut serta dalam upaya implementasi kebijakan ini. Hal ini perlu dilakukan karna dalam proses implementasi kebijakan diperlukan adanya kejelasan mengenai kualitas dari para pelaksana diluar dari latar belakang pendidikan dan pengalaman dalam pengambilan keputusan. Secara kuantitas, sumber daya manusia yang ada di desa-desa khususnya para perangkat desa sudah cukup memadai. Adapun aspek kualitas yang perlu diperhatikan. Tidak sedikit dari perangkat desa yang ada di berbagai desa di Kabupaten Barito Kuala yang masih belum mengetahui fungsi dari instansi 
tempat mereka bekerja. Latar belakang pendidikan juga menentukan kualitas dari aparat desa selaku pelaksana kebijakan. Dari desa yang diteliti ditemui beberapa aparat desa yang latar belakang pendidikannya tidak sesuai dengan kualifikasi pekerjaannya.

Ketidaksesuaian ini pada akhirnya akan sangat berpengaruh terhadap kinerja perangkat desa baik secara langsung maupun tidak langsung ketika tanggung jawab yang diberian diluar dari kualifikasi yang dimiliki oleh aparat tersebut. Kemudian adanya aparat desa yang kurang disiplin dan motivasi dalam bekerja. Terdapat salah satu desa yang beberapa aparatnya jarang masuk bekerja sehingga rekan kerjanya harus menutupi kekosongannya. Hal ini juga menimbulkan tumpang tindih pekerjaan yang akan mengurangi efektivitas dalam bekerja.

Semua instansi dan organisasi
yang bertanggung jawab dalam
pelaksanaan kebijakan Permendes No. 19
Tahun 2017 memiliki fasilitas bekerja
masing-masing. Secara keseluruhan
semua pemerintah desa memiliki fasilitas
masing-masing terutama kantor. Yang
membedakan hanya kondisinya, ada yang
perlu diperluas ada yang sudah dirasa
cukup baik.

Hasil penelitian selanjutnya dikerahui bahwa kecenderungan pelaksana kebijakan Permendes No. 19 Tahun 2017 dapat dilihat dari programprogram apa saja yang telah direncanakan dan diwujudkan, serta bagaimana umpan balik dari masyarakat terhadap pelaksanaan program-program tersebut. Adanya perencanaan, pelaksanaan serta umpan balik tersebut dapat merefleksikan atau menggambarkan perilaku pelaksana kebijakan terhadap kebijakan yang telah ditetapkan. Perilaku atau sikap para pelaksana kebijakan dalam penelitian ini menujukkan hasil yang positif karena seluruh aparatur pemerintah kabupaten, kecamatan dan desa di Kabupaten Barito Kuala mendukung adanya penetapan prioritas penggunaan dana desa dan melaksanakan fungsinya. Meskipun ada perbedaan pendapat, tetapi perbedaan tersebut dapat diselesaikan melalui musyawarah.

Secara kesuluruhan struktur birokrasi masing-masing desa cukup baik. Hanya saja yang perlu menjadi perhatian disini adalah struktur birokrasi dalam cakupan yang lebih luas dalam upaya implementasi Permendes No. 19 tahun 2017. Aparat-aparat desa selaku pelaksana kebijakan yang ada di desadesa secara struktur birokrasi ada dibawah Kementrian Dalam Negeri, sedangkan Permendes No. 19 tahun 2017 dikeluarkan oleh Kemendesa. Sehingga hal ini perlu menjadi perhatian agar Permendes No. 19 Tahun 2017 bisa terlaksana sesuai dengan tujuannya, maka harus ada kejelasan birokrasi antara Kemendesa dengan desa-desa sasarannya di Kabupaten Barito Kuala dalam penelitian ini.

Penting untuk diketahui bahwa dalam penelitian ini prioritas penggunaan dana desa dilaksanakan lebih berfokus kepada sektor pembangunan infrastruktur dibandingkan sektor lainnya seperti pemberdayaan masyarakat. Contohnya di desa Purwosari 1, sebesar 70\% dana desa digunakan untuk memperbaiki jalan, 
jembatan dan fasilitas fisik lainnya. Hal ini juga terjadi di ketujuh desa lainnya.

\section{PEMBAHASAN}

Permendes Nomor 19 Tahun 2017 merupakan perangkat kebijakan dari pemerintah yang mengatur secara terperinci menenai prioritas penggunaan dana desa di Indonesia pada tahun 2018. Dengan harapan bahwa pemerintah daerah kemudian dapat menggunakan Permendes tersebut sebagai pedoman dan acuan dalam menyusun pedoman teknis penggunaan dana desa serta melakukan pengawasan dan evaluasi terhadap pengelolaan dana desa di setiap desa di Indonesia yang menjadi sasaran pemerintah setiap tahunnya.

Mengutip pengertian mengenai dana desa yang tercantum dalam Permendes No. 19 Tahun 2017 disebutkan bahwa: dana desa adalah dana yang bersumber dari Anggaran Pendapatan dan Belanja Negara yang diperuntukkan bagi desa yang ditransfer melalui Anggaran Pendapatan dan Belanja Daerah kabupaten/kota dan digunakan untuk mendanai penyelenggaraan pemerintahan, pelaksanaan pembangunan, pembinaan kemasyarakatan, dan pemberdayaan masyarakat. [2]

Berdasarkan hasil penelitian yang telah dilakukan kepada delapan desa yang ada di beberapa kecamatan di Kabupaten Barito Kuala dapat dilihat sejauh mana implementasi dari Permendes No. 19 Tahun 2017 tentang prioritas penggunaan dana desa terlaksana. Meskipun para perangkat desa tidak mengetahui adanya peraturan ini, bukan berarti mereka sebagai pelaksana kebijakan di tingkat desa tidak memahami adanya aturan dalam prioritas penggunaan dana desa. Para perangkat desa selaku pelaksana kebijakan mengetahui adanya prioritas dalam penggunaan dana desa melalui beberapa Peraturan Bupati Barito Kuala, khususnya Peraturan Bupati Nomor 109 dan 120 Tahun 2017.

Peraturan Bupati Nomor 109 Tahun 2017 adalah peraturan tentang tata cara pembagian dan penetapan rincian alokasi dana desa yang bersumber dari APBD bagi setiap desa di Kabupaten Barito Kuala tahun anggaran 2018 [10]. Tercantum pada bab IV pasal 8 mengenai penggunaan alokasi dana desa, yaitu: 1) Alokasi Dana Desa diprioritaskan untuk mendanai program dan kegiatan pada bidang penyelenggaraan pemerintahan Desa dan Pembinaan kemasyarakatan Desa; 2) Selain digunakan untuk kegiatan sebagaimana dimaksud pada ayat (1), dapat digunakan untuk mendukung pelaksanaan pembangunan desa, pemberdayaan masyarakat desa, dan belanja tidak terduga; 3) Program dan kegiatan prioritas yang didanai dari Alokasi Dana Desa ditetapkan secara tersendiri dalam pedoman teknis penggunaan dana transfer kepada desa yang ditetapkan melalui peraturan Bupati. [10]

Dari ketiga ayat diatas telah disebutkan beberapa prioritas penggunaan dana desa yaitu pelaksanaan pembangunan desa dan pemberdayaan masyarakat desa seperti yang memang telah diatur dalam Permendes No. 19 tahun 2017. Adapun pedoman teknis prioritas penggunaan dana desa, alokasi dana desa tahun anggaran 2018 yang terdapat dalam Peraturan Bupati Nomor 120 Tahun 2017. Peraturan ini mencantumkan Permendes No. 19 Tahun 2017 sebagai acuan pertimbangan sehingga ditetapkannya Peraturan Bupati tentang pedoman teknis penggunaan dana desa yang mengatur secara terperinci mengenai prioritas kegiatan yang bersumber dari dana desa merupakan 
kegiatan yang dapat memenuhi tujuan dan memberikan dampak di sektor pembangunan dan pemberdayaan masyarakat desa itu sendiri.

Dengan adanya Peraturan Bupati yang mengatur pedoman teknis dalam penggunaan dana desa dan menjadikan Permendes No. 19 Tahun 2017 sebagai acuan pertimbangan, maka dapat dikatakan bahwa tujuan utama dari Permendes No. 19 tahun 2017 itu sendiri telah tercapai. Tujuan tersebut tercantum pada bab II Pasal 2, yaitu: 1) Memberikan acuan bagi penyelenggaraan bagi kewenangan hak asal usul dan kewenangan lokal berskala desa yang dibiayai oleh Dana Desa dalam melaksanakan program dan kegiatan; 2) Memberikan acuan bagi Pemerintah Kabupaten/Kota dalam menyusun pedoman teknis penggunaan Dana Desa; dan 3) Memberikan acuan bagi Pemerintah Daerah Pusat dalam pemantauan dan evaluasi pelaksanaan penggunaan Dana Desa [2].

Pemerintah Kabupaten Barito Kuala telah berhasil melaksanakan apa yang menjadi tujuan dari ditetapkannya Permendes No. 19 Tahun 2017 yaitu menjadikan Permendes sebagai acuan teknis dalam penyusunan pedoman dan pengelolaan dana desa.

Setelah dana desa diterima, masing-masing desa melakukan musyawarah bersama yang disebut dengan "musrenbangdes". Dari sini terlihat adanya bentuk komunikasi yang terjalin antara perangkat desa dan masyarakat. Dalam musyawarahmusyawarah tersebut dibahas mengenai pengalokasian dana desa dan juga masukan-masukan kebutuhan dari masyarakat setempat. Sosialisasi mengenai program-program yang dilakukan yang dibiayai oleh dana desa juga merupakan salah satu wujud berjalannya komunikasi yang mendukung implementasi Permendes ini. Selain sosialisasi program, dilakukan juga sosialisasi untuk mengajar masyarakat desa terlibat langsung dalam kegiatankegiatan untuk mencapai tujuan penggunaan dana desa yang telah ditetapkan. Sosialisasi tersebut merupakan cara berkomunikasi yang sangat diperlukan dalam rangka menjamin agar pesan yang harus disampaikan tidak mengalami distorsi dan dapat dimengerti oleh masyarakat. Sosialisasi dengan melibatkan masyarakat secara langsung inilah yang telah dicapai oleh masyarakat desa yang ada di Kabupaten Barito Kuala.

Berdasarkan hasil penelitian ini, desa-desa di Kabupaten Barito Kuala secara kuantitatif maupun kualitatif ditunjang oleh sumber daya manusia yang cukup kuantitatif dan kualitatif. Banyak pihak yang secara aktif terlibat dalam pengelolaan dana desa. Tidak hanya BPD dan para pelaksana kebijakan di Kantor Desa, tetapi juga terdapat kelompok-kelompok dalam masyarakat yang ikut serta dalam program pengelolaan dana desa. Di setiap desa terdapat LPM, PKK, Karang Taruna dan Gabungan Kelompok Tani (Gapoktan) yang memiliki anggota masing-masing. Jadi secara kuantitas sumber daya manusia sebagai penunjang kebijakan pengelolaan dana desa cukup memadai.

Secara kualitatif pun cukup baik karena masing-masing pihak pelaksana kebijakan tersebut memiliki pengetahuan mengenai fungsi dan tugasnya. Sebagai salah satu contoh seperti yang dijelaskan oleh wakil BPD di desa Purwosari 1 Kecamatan Tambah, bahwa fungsi BPD menurut beliau dalam pemerintahan desa sebenarnya dalam satu atap mendasar mereka adalah pengawasan. Sifatnya dalam proyek itu mengawasi, mengayomi masyarakat. Selain itu BPD juga memfasilitasi kemauan masyarakat dan 
penyambung lidah masyarakat. Selain BPD, perangkat desa dan kelompok masyarakat lainya yang ikut serta dalam pelaksanaan pengelolaan dana desa ini juga memiliki pengetahuan yang cukup baik mengenai apa saja yang dibutuhkan oleh masyarakat setempat.

Sumber daya lainnya yang juga mempengaruhi berjalannya suatu kebijakan menurut Edwards III adalah pendanaan dan fasilitas. Secara pendanaan kebijakan ini sudah cukup jelas yaitu dengan adanya dana desa yang diberikan kepada masing-masing desa untuk dikelola dengan sebaik-baiknya berdasarkan prioritas yang ada. Begitupula dengan fasilitas penujuang kebijakan, para pelaksana kebijakan di desa ini memiliki kantor masing-masing, dan di desa pun ketika berinteraksi dengan masyarakat juga memiliki fasilitas untuk berkumpul bersama.

Jika dilihat dari bagaimana disposisi atau sikap pelaksana terhadap kebijakan yang ditetapkan oeleh pemerintah yang dalam hal ini adalah pelaksana kebijakan terutama aparat desa di Kabupaten barito Kuala. Dan sikap pelaksana kebijakan di desa ini sangat positif. Para perangkat desa mendukung adanya program pengelolaan dana desa dan mereka berusaha melakukanya dengan sebaik-baiknya bersama dengan masyarakat. Para perangkat desa memiliki pemahaman dan komitmen untuk membangun dan memberdayakan masyarakat desa yang menjadi salah satu inti dari Permendes No. 19 Tahun 2017. Struktur birokrasi juga perlu menjadi perhatian dalam terlaksananya sebuah kebijakan. Secara umum birokrasi yang ada di desa-desa di Kabupaten Barito Kualas memiliki struktur yang jelas sesuai dengan fungsinya masing-masing.

Kemudian penetapan prioritas penggunaan dana desa di Kabupaten Barito Kualas lebih mengutamakan pada pembangunan infrastruktur sebanyak $70 \%$ seperti perbaikan, jalan, jembatan dan lain sebagainya. Selain itu melalui dana desa pula dikelola BUM Desa untuk para petani dan juga penjualan LPG. Pembangunan gedung olahraga pun sudah dilaksanakan. Oleh sebab itu dalam pengelolaan dana desa sudah berjalan berdasarkan prioritas penggunaan dana desa yang telah ditetapkan, yaitu pembangunan infrastruktur, pengelolaan BUM Desa dan sarana olahraga, serta adanya publikasi penggunaan dana desa yang biasanya dapat dijumpai di depan kantor desa. Hanya saja ada satu prioritas lain yang sama pentingnya dalam upaya pengentasan kemiskinan di pedasaan yaitu pemberdayaan masyarakat desan di Kabupaten Barito Kuala masih belum terlaksana dengan maksimal. Meskipun sempat pernah dilaksanakan beberapa pelatihan tetapi hal tersebut tidak terlalu mendapat perhatian dari masyarakat dan pada akhirnya hasil yang diharapkan dari pelatihan tersebut sebagai salah satu perwujudan pemberdayaan masyarakat desa belum tercapai.

Terkait dalam upaya peningkatan kulaitas sumber daya manusia khususnya pemerintahan desa di Kabupaten Barito Kuala yang sangat penting untuk diperhatikan karena salah satu indikator penting dalam mewujudkan keberhasilan implementasi sebuah kebijakan adalah sumber daya manusia. Pemerintah Kabupaten Barito Kuala telah berupaya untuk meningkatkan kualitas pemerintahan desa agar memiliki kemampuan dalam memberikan pelayanan prima kepada masyarakat dan meningkatkan kinerjanya. Upaya peningkatan kualitas tersebut diatur secara khusus dalam Peraturan Bupati Barito Kuala Nomor 43 Tahun 2014 tentang Roadmap Pemberdayaan Pemerintah Desa Pada Pemerintahan Kabupaten Barito Kuala Tahun 20152017 [11]. Dengan adanya Peraturan ini 
pemerintahan desa diharapkan dapat meningkatkan kualitas kinerjanya. Dari roadmap ini terlihat jelas adanya komitmen dari Pemerintah Kabupaten Barito Kuala untuk memberdayakan pemerintahan desa sebagai pelaksana kebijakan yang langsung berhubungan dengan masyarakat (street level bureaucrats). Pemberdayaan pemerintahan desa tersebut akan sangat mempengaruhi upaya pelaksaan kebijakan di desa-desa yang ada di Kabupaten Barito Kuala.

\section{KESIMPULAN DAN SARAN}

Kajian implementasi kebijakan pengelolaan dana desan yang dilakukan di Kabupaten Barito Kuala berdasarkan hasil penelitian dan pembahasannya dapat menghasilkan kesimpulan dan beberapa saran sebagai berikut.

Upaya komunikasi kebijakan Permendes No. 19 Tahun 2017, proses transmisi dan kejelasan komunikasinya belum optimal. Karena tidak semua pelaksana kebijakan (perangkat desa) mengetahui nama dari kebijakan tersebut, begitupula mengenai isinya. Para pelaksana kebijakan hanya memiliki informasi mengenai sasaran dan tujuan dari pengalokasian dan pengelolaan dana desa berdasarkan beberapa Peraturan Bupati Barito Kuala khususnya Nomor 120 Tahun 2017. Meskipun tidak mengetahui nama kebijakan yang ditetapkan, seluruh perangkat desa memiliki pengetahuan baik mengenai prioritas dan tujuan dari penggunaan dana desa yang diterima. Komunikasi yang terjalin antar perangkat desa dan juga masyakarat dalam pengelolaan dana desa pun berjalan dengan cukup baik. Sebuah pelaksanaan kebijakan dapat dikatakan efektif jika para pembuat keputusan benar-benar mengetahui dan memahami apa yang harus dan akan dikerjakan.

Sumber daya manuasia yang ada di desa-desa tempat penelitian jika dilihat secara secara kuantitas, sudah cukup memadai tetapi masih dapat ditingkatkan lagi secara kualitatif seperti dengan memperhatikan latar belakang pendidikan aparatur desa.

Dalam penelitian ini kecenderungan disposisi pelaksana kebijakan Permendes No. 19 Tahun 2017 menunjukkan hasil hasil yang positif dimana seluruh aparat pemerintah kabupaten, kecamatan maupun desa yang ada di Barito Kuala sangat mendukung adanya penetapan prioritas penggunaan dana desa dan melaksanakan fungsinya.

Secara kesuluruhan struktur birokrasi masing-masing desa cukup baik. Hanya saja yang perlu menjadi perhatian disini adalah struktur birokrasi dalam cakupan yang lebih luas dalam upaya implementasi Permendes No. 19 tahun 2017. Aparat-aparat desa selaku pelaksana kebijakan yang ada di desadesa secara struktur birokrasi ada dibawah Kementrian Dalam Negeri, sedangkan Permendes No. 19 tahun 2017 dikeluarkan oleh pemerintah khususnya Kemendesa. Sehingga hal ini perlu menjadi perhatian agar Permendes No. 19 Tahun 2017 bisa terlaksana sesuai dengan tujuannya, maka harus ada kejelasan birokrasi antara Kemendesa dengan pemerintah Kabupaten Barito Kuala serta desa-desa yang ada di dalamnya. 
Berdasarkan hasil penelitian terhadap delapan desa dapat disimpulkan bahwa penggunaan dana desa yang selama ini dilaksanakan lebih berfokus kepada sektor pembangunan infrastruktur. Contohnya di desa Purwosari 1, sebesar $70 \%$ dana desa digunakan untuk memperbaiki jalan, jembatan dan fasilitas fisik lainnya. Hal ini juga terjadi di ketujuh desa lainnya. Dengan adanya prioritas yang sangat besar terhadap pembangunan infrastruktur, sektor pemberdayaan masyarakat menjadi tidak maksimal. Selain karena dana yang terbatas, ada pula faktor lain yang mempengaruhi mengapa pemberdayaan masyarakat setempat tidak berkembang, yaitu: kurangnya pelatihan dan kurangnya kemauan masyarakat untuk berpartisipasi. Sehingga dapat disarankan agar pemerintah desa juga memberikan perhatian lebih besar dalam upaya pemberdayaan masyarakat. Dan pemberdayaan masyarakat tersebut diharapkan diselenggarakan dengan menyesuaikan potensipotensi apa saha yang ada di tiap-tiap desa di Kabupaten Barito Kuala.

Jadi dapat ditarik kesimpulan bahwa implementasi dari Permendes No. 19 Tahun 2017 di delapan desa dalam penelitian ini telah terlaksana dengan cukup baik dan masih dapat dioptimalkan lagi. Optimalisasi implementasi kebijakan tersebut bisa dilakukan dengan memperhatikan beberapa kendala yang ada di kedelapan desa tersebut. Pertama, kurangnya transmisi komunikasi mengenai adanya peraturan menteri desa nomor 19 tahun 2017 kepada para aparat desa sebagai pelaksana kebijakan khususnya di Kabupaten Barito Kuala.
Padahal Permendes tersebut telah dijadikan acuan dalam pengelolaan dana desa yang tercantum dalam Peraturan Bupati sebagai tindak lanjut. Kedua, sumber daya yang baik itu sumber daya manusia, informasi dan fasilitas. Dari keseluruhan desa, sumber daya yang ada harus dikembangkan lebih baik lagi untuk menunjang kinerja implementasi penetapan prioritas penggunaan dana desa untuk penanggulangan kemiskinan.

Dan yang menjadi perhatian paling utama dalam penelitian ini adalah sumber daya manusia dari segi kuantitas maupun kualitas. Diharapkan para aparat desa sebagai sumber daya manusia yang bertugas sebagai pelaksana kebijakan dapat meningkatkan kualitas kerjanya. Kualitas tersebut berupa kecakapan dalam bekerja, pengetahuan dan wawasan yang memadai sesuai dengan tugas dan jabatan masing-masing unit kerja, dan latar pendidikan yang lebih baik. Diharapkan roadmap pemberdayaan pemerintahan desa pada Pemerintahan Kabupaten Barito Kuala akan terus dilakukan untuk meningkatkan kualitas kinerja pemerintahan desa.

\section{DAFTAR PUSTAKA}

[1] Fatony, Achmad. (2011). Kebijakan Pengentasan Kemiskinan Berbasis Participatory Poverty Assesment: Kasus Yogyakarta. Sosiokonsepsia, 16 (02): 123-142.

[2] Peraturan Menteri Desa, Pembangunan Daerah Tertinggal, dan Transmigrasi Republik Indonesia Nomor 19 Tahun 2017 Tentang Penetapan Prioritas 
Penggunaan Dana Desa Tahuun 2018.

[3] Nugroho, Rian. 2013. Metode Penelitian Kebijakan.Yogyakarta : Pustaka Pelajar.

[4] Winarno, Budi. (2007). Kebijakan Publik: Teori dan Proses. Yogyakarta: Media Presindo.

[5] Edwards III, George C. (1980). Implementing Public Policy. Washington DC: Congressional Quarterly Press.

[6] Subarsono, A.G. (2005). Analisis Kebijakan Publik: Konsep, Teori dan Aplikasi. Yogyakarta: Pustaka Pelajar.

[7] Vredenberg, Jacob. (1999). Metode dan Teknik Penelitian Masyarakat. Jakarta: Gramedia.

[8] Badan Pusat Statistik Kabupaten Barito Kuala. (2018). Kabupaten Barito Kuala Dalam Angka. BPS Barito Kuala: CV. Karya Bintang Muslim.
[9] Peraturan Bupati Barito Kuala Nomor 120 Tahun 2017 Tentang Pedoman Teknis Prioritas Penggunaan Dana Desa, Alokasi Dana Desa, dan Bagi Hasil Pajak dan Retribusi Daerah Tahun Anggaran 2018.

[10]Peraturan Bupati Barito Kuala Nomor 109 Tahun 2017 Tentang Tata Cara Pembagian dan Penetapan Rincian Alokasi Dana Desa Yang Bersumber Dari APBD Bagi Setiap Desa di Kabupaten Barito Kuala Tahun Anggaran 2018.

[11] Peraturan Bupati Barito Kuala Nomor 43 Tahun 2014 Tentang Roadmap Pemberdayaan Pemerintahan Desa Pada Pemerintah Kabupaten Barito Kuala Tahun 2015-2017. 